ORIGINAL ARTICLE

\section{Carbon in Airway Macrophages and Lung Function in Children}

\author{
Neeta Kulkarni, M.D., Nevil Pierse, M.Sc., Lesley Rushton, Ph.D., \\ and Jonathan Grigg, M.D.
}

\section{A BSTRACT}

\section{BACKGROUND}

Epidemiologic studies indirectly suggest that the inhalation of carbonaceous particulate matter impairs lung function in children. Using the carbon content of airway macrophages as a marker of individual exposure to particulate matter derived from fossil fuel, we sought direct evidence of this association.

\section{METHODS}

Airway macrophages were obtained from healthy children through sputum induction, and the area of airway macrophages occupied by carbon was measured. Lung function was measured with the use of spirometry. We modeled the exposure to primary particulate matter (PM) that is less than $10 \mu \mathrm{m}$ in aerodynamic diameter $\left(\mathrm{PM}_{10}\right)$ at or near each child's home address. Linear regression was used to evaluate associations between carbon content of alveolar macrophages and variables that may affect individual exposure. To determine whether lung function that is reduced for other reasons is associated with an increase in the carbon content of airway macrophages, we also studied children with severe asthma.

\section{RESULTS}

We were able to assess the carbon content of airway macrophages in 64 of 114 healthy children (56 percent). Each increase in primary $\mathrm{PM}_{10}$ of $1.0 \mu \mathrm{g}$ per cubic meter was associated with an increase of $0.10 \mu \mathrm{m}^{2}$ (95 percent confidence interval, 0.01 to 0.18 ) in the carbon content of airway macrophages, and each increase of $1.0 \mu \mathrm{m}^{2}$ in carbon content was associated with a reduction of 17 percent ( 95 percent confidence interval, 5.6 to 28.4 percent) in forced expiratory volume in one second, of 12.9 percent (95 percent confidence interval, 0.9 to 24.8 percent) in forced vital capacity, and of 34.7 percent ( 95 percent confidence interval, 11.3 to 58.1 percent) in the forced expiratory flow between 25 and 75 percent of the forced vital capacity. The carbon content of airway macrophages was lower in children with asthma than in healthy children.

\section{CONCLUSIONS}

There is a dose-dependent inverse association between the carbon content of airway macrophages and lung function in children. We found no evidence that reduced lung function itself causes an increase in carbon content.
From the Division of Child Health, Department of Infection, Immunity, and Inflammation (N.K., J.G.), and the Institute for Environment and Health (N.P., L.R.), University of Leicester, Leicester, United Kingdom. Address reprint requests to Prof. Grigg at the Institute of Cell and Molecular Science, Barts and the London, Queen Mary's School of Medicine and Dentistry, 4 Newark St., London El 2AT, United Kingdom, or at j.grigg@qmul.ac.uk.

N Engl J Med 2006;355:21-30.

Copyright (c) 2006 Massachusetts Medical Society. 
B LACK CARBON IS A MAJOR COMPONENT of inhalable particulate matter (particulate matter $<10 \mu \mathrm{m}$ in aerodynamic diameter $\left[\mathrm{PM}_{10}\right]$ ) directly emitted from the combustion of fossil fuels. ${ }^{1}$ Black carbon consists of a carbon core enriched with trace metals and organic compounds, and it is thought to mediate many of the adverse health effects reported in epidemiologic studies to be associated with $\mathrm{PM}_{10}{ }^{2}$ Children are especially vulnerable to the adverse effects of $\mathrm{PM}_{10},{ }^{2}$ with the cumulative effects on the growth of lung function of particular concern. For example, Gauderman et al. ${ }^{3}$ studied air pollution data from monitoring stations in 12 California communities and reported that increased exposure to elemental carbon and gases from fuel combustion and $\mathrm{PM}_{10}$ was associated with impaired growth of lung function.

Airway macrophages are the primary phagocyte for inhaled PM, and in animal models, the amount of carbon-pigmented material in airway macrophages has been shown to reflect both the inhaled dose $^{4}$ and the total particulate burden in the lung. ${ }^{5}$ In adults, the amount of carbonaceous particles extracted from the lung at autopsy reflects the long-term exposure to $\mathrm{PM}_{10},{ }^{6}$ and $\mathrm{PM}$ in airway macrophages reflects exposure to inhalable PM in occupational settings. ${ }^{7}$ In this study, we sought to determine the association between the carbon content of airway macrophages and lung function in a group of healthy children and the association between carbon content and variables that may affect individual exposure - such as exercise, ${ }^{8}$ body-mass index, ${ }^{9}$ sex,${ }^{10}$ and levels of $\mathrm{PM}_{10}$ derived from vehicle traffic at or near the home address. ${ }^{11}$ To address the possibility of reverse causation namely, that reduced lung function causes an increase in the carbon content of airway macrophages - we also assessed the carbon content of airway macrophages in children who showed evidence of the chronically reduced lung function that is associated with long-standing severe asthma.

\section{METHODS}

The study was conducted in Leicester, a mediumsized city in the United Kingdom with annual mean levels of total $\mathrm{PM}_{10}$ within U.K. air-quality recommendations. ${ }^{12}$ The study protocol was approved by the institutional review board of the Leicestershire Research Ethics Committee. The parents of the healthy children gave written informed consent, and the children gave written assent. Airway macrophages from children with asthma, which had been obtained as part of normal clinical management, were analyzed with the approval of the institutional review board.

\section{SUBJECTS}

Healthy children were recruited from local schools. Children were included if they were 8 to 15 years of age, were living in Leicestershire, and were living in the same house they had lived in for at least one year before the study began and if their parents reported that they had normal levels of activity. We excluded children who had any chronic respiratory condition, symptoms consistent with a respiratory infection over the previous three months, passive exposure to tobacco smoke at home, or exposure to unusual sources of combustion particles (such as from incense sticks); children who were smokers; or children who lived in a house heated by coal combustion. To ensure that the carbon content of airway macrophages reflected exposures in Leicester, we also excluded children who had spent more than 5 days outside the city in the previous 3 months (the half-life of particles in airway macrophages after a single instilled dose is 3.9 months $^{13}$ ). Since the PM exposure model we used is not valid for buildings more than two stories high, we excluded children whose home was located above the second floor. For safety reasons, children with a post-bronchodilator forced expiratory volume in one second $\left(\mathrm{FEV}_{1}\right)$ of less than 80 percent of the predicted value were also excluded.

Sputum induction was performed on various days from November 2002 through December 2003 at the Leicester Royal Infirmary. On the study day, children and parents together completed a questionnaire that requested the child's age, sex, number of siblings, race, and home address. The child's body-mass index was calculated from the height and weight on that day. The child also completed a separate questionnaire, from which metabolic and vigorous activity scores were determined $^{14,15}$ (additional methods are listed in the Supplementary Appendix, available with the full text of this article at www.nejm.org). Exposure to environmental tobacco smoke was assessed with the collection of saliva samples from each child, which were tested for cotinine according to a gas-liquid chromatographic method with a detec- 
tion limit of $0.1 \mathrm{ng}$ per milliliter in a commercial laboratory (ABS Laboratory). ${ }^{16}$ In the cotinine assay, a level of $14.3 \mathrm{ng}$ per milliliter or less rules out active smoking, ${ }^{17}$ and a level of 1.2 ng per milliliter is the 90th percentile value for children who live with no adult smokers. ${ }^{18}$

Children with asthma were identified retrospectively from those referred for sputum induction (to assess airway eosinophilia) from a clinic for severe asthma from January 2002 through October 2005. All children with asthma had chronic persistent wheeze and cough while taking inhaled beclomethasone dipropionate at a dosage of $800 \mu \mathrm{g}$ or more per day and an inhaled longacting $\beta_{2}$-agonist twice daily. Demographic, treatment, and spirometric data on the day of sputum induction were obtained from a retrospective review of the clinical records. Activity data were not obtained. In this group, in contrast to the healthy group, an $\mathrm{FEV}_{1}$ of less than 80 percent of the predicted value did not preclude sputum induction.

\section{LUNG FUNCTION}

Lung function was recorded no more than $20 \mathrm{~min}$ utes before sputum induction with the use of a $\mathrm{Vi}$ talograph 2120 spirometer and Vitalograph 2120 Spirotrac IV software. This system was compliant with the recommendations of the American Thoracic Society and the European Respiratory Society for lung function in children. ${ }^{19,20}$ Spirometry was conducted according to the recommendations of the American Thoracic Society. ${ }^{19} \mathrm{FEV}_{1}$, forced vital capacity (FVC), forced expiratory flow between 25 and 75 percent of the FVC $\left(\mathrm{FEF}_{25-75}\right)$ and the $\mathrm{FEV}_{1}$ :FVC ratio were used as the primary variables of lung function. Each plot of the flow rate against volume during an FVC maneuver (flow volume curve) was visually examined for each child, and if the final expiratory phase was stopped owing to a Valsalva maneuver or hesitation but the first portion of the curve was acceptable, only the $\mathrm{FEV}_{1}$ was calculated.

Lung function was measured both before and 15 minutes after a dose of $200 \mu \mathrm{g}$ of albuterol was given by means of a Volumatic metered-dose inhaler with a spacer (Allen and Hanburys). Pre- and post-bronchodilator lung function was expressed as the percentage of the predicted normal value - according to reference equations that adjusted for height, weight, sex, and race ${ }^{21,22}$ - and as a $z$ score based on a reference population from the
United Kingdom, which was adjusted for height and sex but not race. ${ }^{23}$

\section{INDUCED SPUTUM}

Sputum induction was conducted in healthy children and children with asthma according to a standard method. ${ }^{24}$ Nebulized saline (4.5 percent) was administered through an ultrasonic nebulizer (Sonix 2000, Clement Clarke International) in three sequential five-minute inhalation periods. $\mathrm{FEV}_{1}$ was measured throughout the inhalation periods for the detection of clinically significant bronchoconstriction. Induced sputum was processed according to a standard technique. ${ }^{25}$ Dithiothreitol (Sigma) was used as a mucolytic agent, and airway cells were removed. The airway cells were cytocentrifuged (Cytospin, Shandon Scientific) onto glass slides according to a standard method, ${ }^{26}$ and stained with Diff-Quik (Dade Behring). The induced-sputum leukocyte differential was measured in 300 nonsquamous nucleated cells per child.

\section{CARBON CONTENT OF AIRWAY MACROPHAGES}

Airway macrophages were visualized by light microscopy. The area occupied by black material (carbon) in each macrophage was assessed as previously described ${ }^{27}$ by an investigator who was blinded to lung function. Scion Image software was used to calculate the carbon content of airway macrophages, which was defined a priori as the median area occupied by carbon $\left(\mu \mathrm{m}^{2}\right)$ in 100 randomly selected cells per child.

\section{MODELED PRIMARY PM 10}

The annual mean level of primary $\mathrm{PM}_{10}$ - that is, the component of $\mathrm{PM}_{10}$ emitted directly from local sources of combustion - was calculated for each child's home address using the Airviro dispersion model (Swedish Meteorological and Hydrological Institute), ${ }^{28}$ as previously reported. ${ }^{11}$ Specifically, we modeled the hourly emissions of primary $\mathrm{PM}_{10}$ from road traffic using Airviro and a database containing estimates for hourly traffic flows, speeds, and vehicular mixes (e.g., cars vs. trucks). The dispersion of primary $\mathrm{PM}_{10}$ was calculated with the use of the actual wind speed and direction measured for the time period. ${ }^{11}$

\section{STATISTICAL ANALYSIS}

Data were summarized as means \pm SD or medians and ranges. The baseline characteristics of the 


\begin{tabular}{|c|c|c|c|}
\hline Characteristic & $\begin{array}{l}\text { Healthy Children } \\
\qquad(\mathrm{N}=64)\end{array}$ & $\begin{array}{l}\text { Children with Asthma } \\
\qquad(\mathrm{N}=9)\end{array}$ & P Value \\
\hline Age $-y r$ & $11.5 \pm 2.3$ & $13.6 \pm 2.0$ & 0.009 \\
\hline Male sex — no. (\%) & $35(55)$ & $5(56)$ & 0.96 \\
\hline Race - no. $(\%) \dagger$ & & & 0.68 \\
\hline White & $40(62)$ & $5(56)$ & \\
\hline Nonwhite & $24(38)$ & $4(44)$ & \\
\hline Weight — kg & $45.5 \pm 13.4$ & $49.8 \pm 13.6$ & 0.36 \\
\hline Height $-\mathrm{cm}$ & $149.8 \pm 13.2$ & $153.7 \pm 8.7$ & 0.37 \\
\hline Body-mass index & $19.9 \pm 3.8$ & $21.01 \pm 5.2$ & 0.44 \\
\hline $\mathrm{FEV}_{1}-\%$ of predicted value & $100.1 \pm 11.1$ & $71.8 \pm 13.0$ & $<0.001$ \\
\hline FVC - \% of predicted value & $103.0 \pm 11.2$ & $92.5 \pm 15.4$ & 0.02 \\
\hline Eosinophils in sputum — \% & & & $<0.001$ \\
\hline Median & 0.25 & 31.17 & \\
\hline Range & $0-35$ & $4-75$ & \\
\hline Carbon content of airway macrophages $-\mu \mathrm{m}^{2}$ & & & $<0.001$ \\
\hline Median & 0.41 & 0.00 & \\
\hline Range & $0.03-1.14$ & $0.00-0.12$ & \\
\hline Modeled annual mean primary $\mathrm{PM}_{10}-\mu \mathrm{g} / \mathrm{m}^{3} \uparrow$ & & & 0.02 \\
\hline Median & 1.21 & 1.81 & \\
\hline Range & $0.10-2.71$ & $0.17-2.13$ & \\
\hline
\end{tabular}

healthy group and the group with asthma were compared with the use of an unpaired t-test for the means, the chi-square test for the proportions, and the Mann-Whitney test for skewed data. Normal linear models were used to explore the associations between variables. Q-Q plots of the residuals, the residuals versus the fitted values, and the residuals versus leverage were used to test the assumptions of all linear models. We also used nonparametric tests in the place of linear regression to confirm the results. In the multiple regression models, confounders were included if they were significant at a 0.05 level or they altered the coefficient of the main variable by more than 10 percent in cases in which the main association was significant. The potential confounding variables considered were age, sex, race, weight, height, birth order, number of siblings, exercise measures, and cotinine levels in saliva. A P value of less than 0.05 was considered to indicate statistical significance, and reported $\mathrm{P}$ values are twosided. Analyses were carried out with the use of SAS version 8.2 for Windows, $\mathrm{R}$ version 2.2.0 (www.r-project.org), and SPSS version 12.0.1 for Windows.

\section{RESULTS}

Sufficient numbers of airway macrophages for an assessment of the area occupied by carbon were obtained from 64 of the 114 healthy children (56 percent) from whom sputum was induced (Table 1 and Fig. 1). There were no significant differences in the demographic variables between children in whom sufficient numbers of airway macrophages were obtained and children in whom insufficient numbers were obtained (Table 1 in the Supplementary Appendix). Cotinine levels in saliva from all children were below the level that indicates active smoking, and 62 of the 64 children had cotinine levels below the 90th percentile for households of nonsmokers. ${ }^{18}$

In healthy children, there was no association between the carbon content of airway macrophages and age, weight, height, body-mass index, activity scores, or cotinine level in saliva, according 


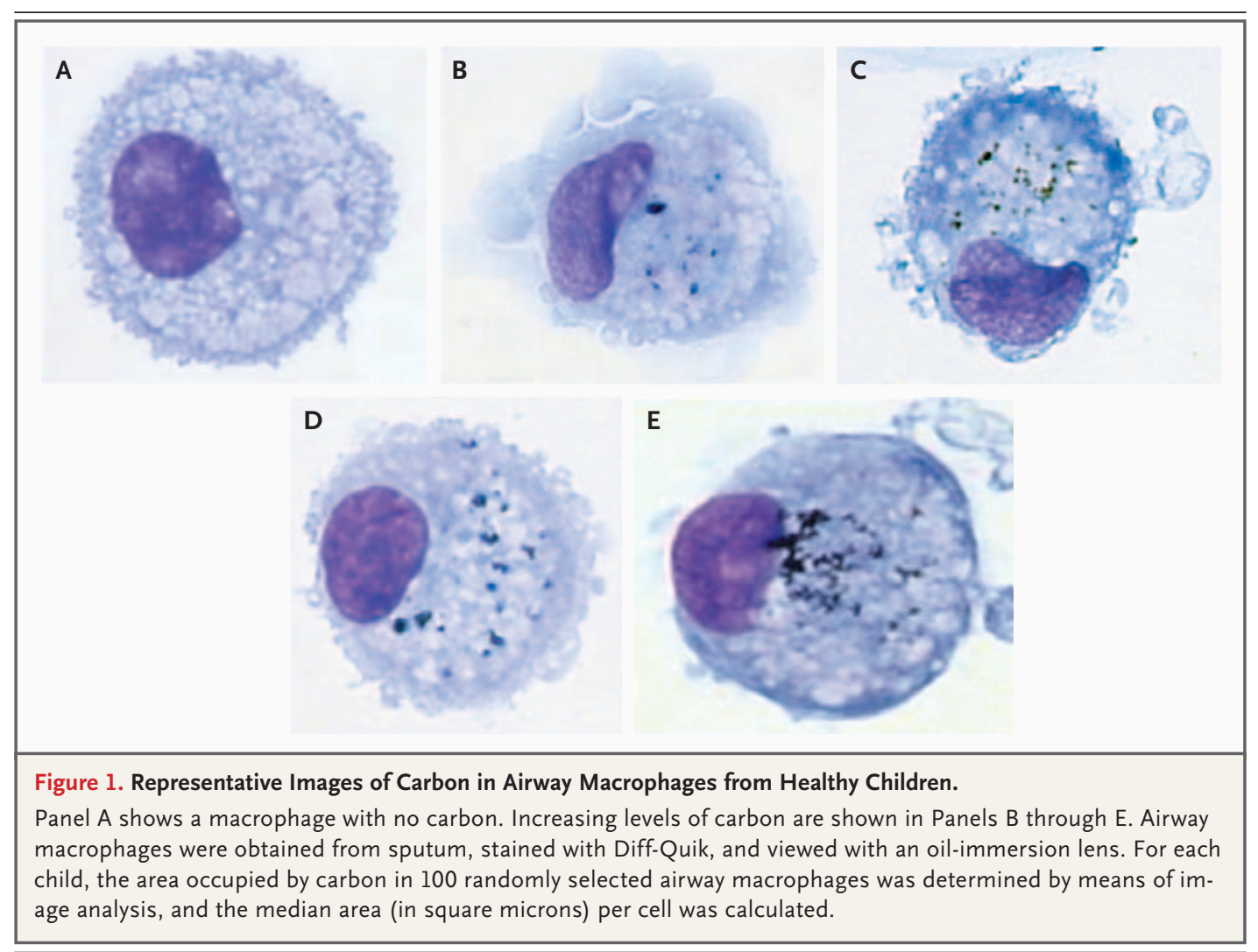

to parametric and nonparametric analyses (Table 2 in the Supplementary Appendix). There was no significant difference in carbon content between boys and girls $(\mathrm{P}=0.59)$. Race was the only variable to reach a significance level high enough to be considered for multiple regression $(\mathrm{P}<0.001)$.

There was an inverse, dose-dependent association between the carbon content of airway macrophages and lung function: each increase of $1.0 \mu \mathrm{m}^{2}$ in carbon content was associated with a reduction of 17 percent ( 95 percent confidence interval, 5.6 to 28.4 percent) in the percentage of the predicted $\mathrm{FEV}_{1}$, of 12.9 percent ( 95 percent confidence interval, 0.9 to 24.8 percent) in FVC, and of 34.7 percent ( 95 percent confidence interval, 11.3 to 58.1 percent) in $\mathrm{FEF}_{25-75}$ (Fig. 2 and Table 2). There was no association between the carbon content of airway macrophages and the $\mathrm{FEV}_{1}$ :FVC ratio. These inverse associations remained significant when lung function was expressed as a $\mathrm{z}$ score or measured 15 minutes after the administration of an inhaled bronchodilator (Table 2).

The annual mean level of primary $\mathrm{PM}_{10}$ at or near the home address was modeled for all healthy children from whom sputum was induced (Table 1). Each increase of $1.0 \mu \mathrm{g}$ per cubic meter in modeled primary $\mathrm{PM}_{10}$ was associated with a $0.10 \mu \mathrm{m}^{2}$ (95 percent confidence interval, 0.01 to 0.18 ) increase in the carbon content of airway macrophages. Increased primary $\mathrm{PM}_{10}$ was inversely associated with the percentage of the predicted $\mathrm{FEV}_{1}(\mathrm{P}=0.04)$ and the $\mathrm{FEF}_{25-75}(\mathrm{P}=0.05)$. In the multiple regression analysis, even after adjusting for the carbon content of $\mathrm{PM}_{10}$, the carbon content of airway macrophages remained inversely associated with the percentage of the predicted values of $\mathrm{FEV}_{1}, \mathrm{FVC}$, and $\mathrm{FEF}_{25-75}(\mathrm{P}=0.02, \mathrm{P}=0.04$, and $\mathrm{P}=0.02$, respectively), whereas $\mathrm{PM}_{10}$ was no longer significantly associated with lung function (Table 3). The stratification of exposure by race showed that nonwhite children had higher modeled primary $\mathrm{PM}_{10}$ at or near the home address than white children ( $\mathrm{P}<0.001)$ (Fig. 3).

Sufficient airway macrophages were obtained from all nine of the nine children with asthma from whom sputum was induced (Table 1). Modeling indicated that, as compared with healthy children, children with asthma lived in areas with increased levels of primary $\mathrm{PM}_{10}(\mathrm{P}=0.02)$, had a 


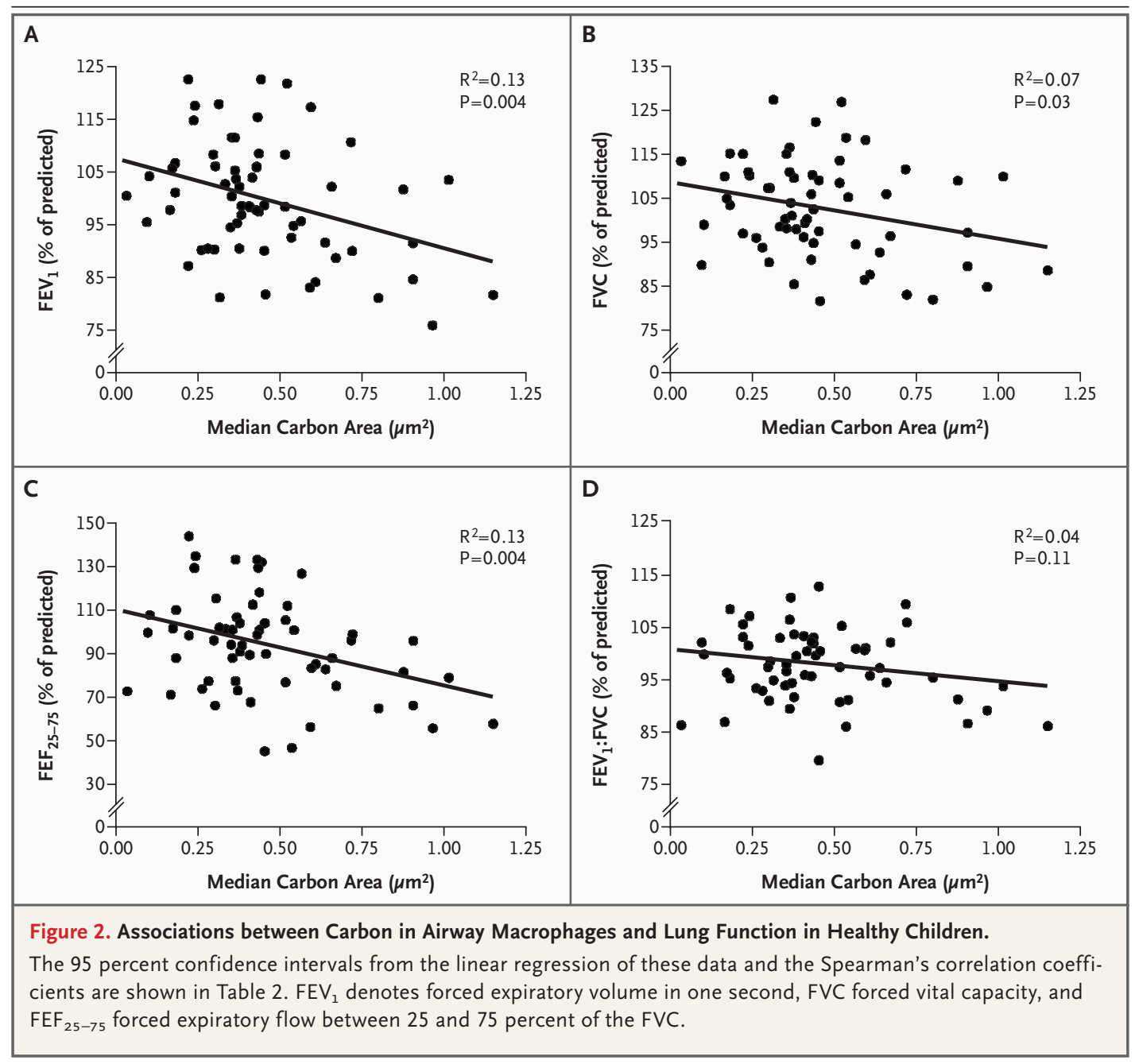

reduced prebronchodilator $\mathrm{FEV}_{1}(\mathrm{P}<0.001)$, and had an increased proportion of eosinophils in sputum $(\mathrm{P}<0.001)$ (Table 1). There was a marked difference in the pattern of carbon loading in airway macrophages between children with asthma and healthy children. Specifically, carbon was not detected in the majority of airway macrophages from children with asthma, whereas the majority of airway macrophages from healthy children contained at least one area of carbon. Thus, the median area occupied by carbon, calculated from 100 cells per child, was 0 for 8 of the 9 children with asthma (Table 1).

\section{DISCUSSION}

We found an inverse, dose-dependent association between the carbon content of airway macrophages and $\mathrm{FEV}_{1}$, FVC, and $\mathrm{FEF}_{25-75}$ in healthy chil- dren living in an area where the spatial variation in $\mathrm{PM}_{10}$ is primarily due to emissions from road traffic. This inverse association is consistent with those reported in epidemiologic studies, which suggest a long-term effect of PM on lung function in children.

The most recent cross-sectional analysis of the cohort of 12 Southern California communities showed that a greater proportion of young adults with an $\mathrm{FEV}_{1}$ of less than 80 percent of the predicted value than of those with a higher $\mathrm{FEV}_{1}$ live in communities with high levels of elemental carbon and $\mathrm{PM}_{10}{ }^{3}$ Similarly, in their three-year study of eight European communities, Horak et al. ${ }^{29}$ found reduced growth of $\mathrm{FEV}_{1}$ and $\mathrm{FEF}_{25-75}$ in children exposed to high levels of $\mathrm{PM}_{10}$ in summer. An adverse effect of $\mathrm{PM}_{10}$ on lung growth is a plausible explanation for the 3.8 percent difference in $\mathrm{FEV}_{1}$ values reported in a cross-sectional 


\begin{tabular}{|c|c|c|c|c|}
\hline \multirow[t]{2}{*}{ Lung-Function Variable'̄ं } & \multicolumn{2}{|c|}{ Linear Regression } & \multicolumn{2}{|c|}{ Spearman's Rank Test } \\
\hline & Coefficient $(95 \% \mathrm{Cl}) \succcurlyeq$ & P Value & r & PValue \\
\hline \multicolumn{5}{|l|}{$\mathrm{FEV}_{1}(\mathrm{~N}=64)$} \\
\hline$\%$ of predicted value & $-17.0(-28.4$ to -5.6$)$ & 0.004 & -0.30 & 0.02 \\
\hline z score & $-2.0(-3.1$ to -0.9$)$ & $<0.001$ & -0.40 & 0.001 \\
\hline \multicolumn{5}{|l|}{ FVC $(N=61)$} \\
\hline$\%$ of predicted value & $-12.9(-24.8$ to -0.9$)$ & 0.03 & -0.24 & 0.05 \\
\hline z score & $-2.3(-3.4$ to -1.1$)$ & $<0.001$ & -0.46 & $<0.001$ \\
\hline \multicolumn{5}{|l|}{$\mathrm{FEF}_{25-75}(\mathrm{~N}=61)$} \\
\hline$\%$ of predicted value & $-34.7(-58.1$ to -11.3$)$ & 0.004 & -0.30 & 0.02 \\
\hline z score & $-1.2(-2.2$ to -0.2$)$ & 0.01 & -0.31 & 0.02 \\
\hline \multicolumn{5}{|l|}{$\mathrm{FEV}_{1}: \mathrm{FVC}(\mathrm{N}=60)$} \\
\hline$\%$ of predicted value & $-6.1(-13.7$ to 1.5$)$ & 0.11 & -0.12 & 0.34 \\
\hline z score & $-0.2(-1.0$ to 0.6$)$ & 0.58 & -0.09 & 0.47 \\
\hline \multicolumn{5}{|c|}{ Post-bronchodilator $\mathrm{FEV}_{1}(\mathrm{~N}=63)$} \\
\hline$\%$ of predicted value & $-15.9(-27.3$ to -4.4$)$ & 0.007 & -0.27 & 0.03 \\
\hline z score & $-2.0(-3.1$ to -0.9$)$ & 0.001 & -0.39 & 0.002 \\
\hline
\end{tabular}

* Carbon in airway macrophages was defined as the median area (in square micrometers) occupied by carbon. $\mathrm{Cl}$ denotes confidence interval, $\mathrm{FEV}_{1}$ forced expiratory volume in one second, FVC forced vital capacity, and FEF $\mathrm{F}_{25-75}$ forced expiratory flow between 25 and 75 percent of the FVC.

$\uparrow$ Percentages of the predicted values for lung function were adjusted for height, weight, sex and race; $z$ score was adjusted for height and weight but not race. FVC and $\mathrm{FEF}_{25-75}$ were not calculated for all children (see the Methods section).

One child did not receive albuterol.

$\ddagger$ The coefficient is of the change in lung function for each increase of $1.0 \mu \mathrm{m}^{2}$ in the carbon content of airway macrophages.

study of children living in areas with high levels and those living in areas with low levels of particulate pollution in Wuhan, China. ${ }^{30}$ In the present study, we modeled primary $\mathrm{PM}_{10}$ at or near the home address. Modeling allowed us to estimate small-scale spatial variations in the levels of traffic-derived $\mathrm{PM}_{10}$. However, our modeling of the primary $\mathrm{PM}_{10}$ did not account for exposures due to personal factors (such as time spent indoors and other activity patterns), did not estimate background exposures to $\mathrm{PM}_{10}$ blown into the study area from other counties, and did not specifically model $\mathrm{PM}_{2.5}$ - the PM fraction that contains the highest proportion of elemental carbon. ${ }^{1}$ Although the true relation of exposure to primary $\mathrm{PM}_{10}$ and the carbon content of airway macrophages may therefore be stronger than that found in the present study, our group recently reported an independent association between modeled primary $\mathrm{PM}_{10}$ at or near the home address and the prevalence and incidence of respiratory symptoms in a cohort of 4400 preschool children. ${ }^{11}$

An alternative explanation for the inverse asso- ciation between the carbon content of airway macrophages and lung function is that low-to-normal lung function increases the deposition of inhaled carbonaceous PM in the airway. We hypothesized that, if low lung function is a major cause of increased carbon content of airway macrophages, then high levels of carbon would be found in the airway macrophages of children with chronic asthma. We found lower levels of carbon in the airway macrophages of children with asthma, despite the higher levels of modeled primary $\mathrm{PM}_{10}$, than in healthy children. This finding suggests that the phagocytosis of carbon particles by airway macrophages may be impaired in severe asthma. Indeed, Alexis et al. ${ }^{31}$ reported the significant impairment of phagocytosis of IgG-opsonized yeast by airway macrophages in a subgroup of adults with asthma who had eosinophilia in their induced sputum.

In experimental exposure studies, increased activity level, reduced age, and increased bodymass index have been shown to cause an increase in particle deposition in the lower airway. ${ }^{8-10}$ In 


\begin{tabular}{|c|c|c|c|c|c|}
\hline Model & Variable & Coefficient $(95 \% \mathrm{Cl}) \dagger$ & $\begin{array}{c}\text { P Value } \\
\text { for Variable }\end{array}$ & $\begin{array}{c}R^{2} \\
\text { for Model }\end{array}$ & $\begin{array}{l}\text { P Value } \\
\text { for Model }\end{array}$ \\
\hline $\mathrm{FEV}_{1}$ vs. $\mathrm{PM}_{10}$ & $\mathrm{PM}_{10}$ & $-4.3(-8.5$ to -0.2$)$ & 0.04 & 0.06 & 0.04 \\
\hline \multirow[t]{3}{*}{$\mathrm{FEV}_{1}$ vs. $\left(\mathrm{PM}_{10}+\mathrm{AM}\right.$ carbon $)$} & & & & 0.15 & 0.006 \\
\hline & $\mathrm{PM}_{10}$ & $-2.9(-6.9$ to 1.2$)$ & 0.17 & & \\
\hline & AM carbon & $-14.7(-26.3$ to -3.2$)$ & 0.02 & & \\
\hline FVC vs. $\mathrm{PM}_{10}$ & $\mathrm{PM}_{10}$ & $-1.2(-5.6$ to 3.2$)$ & 0.59 & 0.005 & 0.59 \\
\hline \multirow[t]{3}{*}{ FVC vs. (PM ${ }_{10}+A M$ carbon $)$} & & & & 0.07 & 0.10 \\
\hline & $\mathrm{PM}_{10}$ & $0.1(-4.4$ to 4.6$)$ & 0.96 & & \\
\hline & AM carbon & $-13.0(-25.6$ to -0.4$)$ & 0.04 & & \\
\hline $\mathrm{FEF}_{25-75}$ vs. $\mathrm{PM}_{10}$ & $\mathrm{PM}_{10}$ & $-8.6(-17.3$ to 0.1$)$ & 0.05 & 0.06 & 0.05 \\
\hline \multirow[t]{3}{*}{$\mathrm{FEF}_{25-75}$ vs. (PM $10+\mathrm{AM}$ carbon $)$} & & & & 0.15 & 0.008 \\
\hline & $\mathrm{PM}_{10}$ & $-5.5(-14.2$ to 3.1$)$ & 0.21 & & \\
\hline & AM carbon & $-30.4(-54.6$ to -6.1$)$ & 0.02 & & \\
\hline
\end{tabular}

* $\mathrm{PM}_{10}$ was defined as the annual mean modeled particulate matter less than $10 \mu \mathrm{m}$ in aerodynamic diameter modeled at or near the home address (in micrograms per cubic meters). AM carbon was defined as the median area (in square micrometers) occupied by carbon in airway macrophages. $\mathrm{Cl}$ denotes confidence interval, $\mathrm{FEV}_{1}$ forced expiratory volume in one second, FVC forced vital capacity, and $\mathrm{FEF}_{25-75}$ forced expiratory flow between 25 and 75 percent of the FVC.

$\uparrow$ The coefficient is of the change in lung function variable for each increase of $1.0 \mu \mathrm{m}^{2}$ in the carbon content in airway macrophages or increase of $1.0 \mu \mathrm{g}$ per cubic meter in modeled annual mean primary $\mathrm{PM}_{10}$ at or near the home address.

the present study, none of these variables were associated with carbon in airway macrophages. A larger study may therefore be needed to identify the independent effects of these variables under normal exposure conditions. However, we found that nonwhite children lived in areas with higher modeled primary $\mathrm{PM}_{10}$ and had higher levels

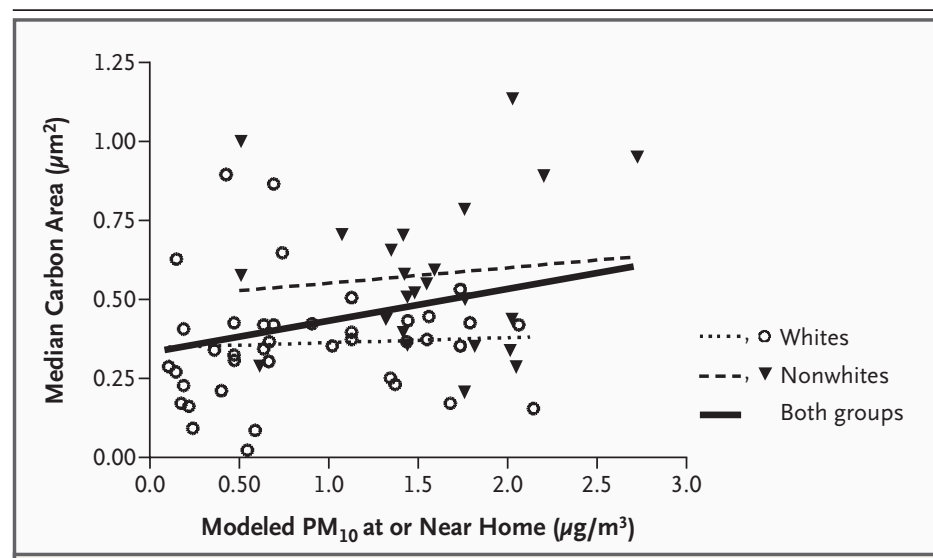

Figure 3. Relation between Modeled Annual Mean Primary PM $_{10}$ at or near the Home Address and Carbon in Airway Macrophages in Healthy Children. The carbon content of airway macrophages was higher in nonwhite than in white healthy children (mean, 0.58 vs. $0.36 \mu \mathrm{m}^{2} ; \mathrm{P}<0.001$ ). For all healthy children combined, $R^{2}$ was $0.081(P=0.02)$ and Spearman's correlation coefficient was $0.30(P=0.01)$. Separate regression lines are also given for white and nonwhite children $(\mathrm{P}=0.74$ and $\mathrm{P}=0.65$, respectively). of carbon in their airway macrophages than did white children. Similarly, a study in the United Kingdom that linked Airviro assessment of traffic-derived air pollution to race at or near the home address found higher exposures for nonwhite than white households. ${ }^{32}$

There are limitations to our study. It is unclear whether the inverse association between the carbon content of airway macrophages and lung function represents a short-term or a long-term effect on lung function. Our results have, however, ruled out short-term reversible bronchoconstriction, since significant inverse associations remained after bronchodilator therapy. It is also unclear whether the carbon content of airway macrophages reflects long-term or short-term exposure to $\mathrm{PM}_{10}$. However, some carbon will have been acquired several months before our analysis, since soot has been observed in airway macrophages at least 10 months after brief occupational exposures, ${ }^{7}$ and insoluble particles remain in airway macrophages for up to 3 months after instillation in experimental studies. ${ }^{13}$ The carbon content of airway macrophages may not reflect the content in more distal alveolar cells, since sputum induction samples macrophages from the larger airways. ${ }^{33}$ In adults, however, the distribution of particles from the environment in bronchial mac- 
rophages is nearly identical to that in alveolar macrophages. ${ }^{13,34}$ Our limited success rate of 56 percent for sputum induction in healthy children may have introduced bias, although this rate is similar to that for healthy children reported in a previous study, ${ }^{35}$ and there were no differences in any other measured variables between children from whom sputum was induced successfully and those from whom it was not.

We have not proved that the black material in airway macrophages is elemental carbon. In a previous study, our group found that particles in alveolar macrophages from healthy children were morphologically identical to aggregates of carbon nanoparticles from emissions of primary diesel exhaust, ${ }^{36}$ and a preliminary analysis by means of electron energy-loss spectroscopy of the airway macrophages in the present study found no spectra indicating the presence of iron, titanium, sili$\mathrm{ca}$, or sulfur (Geiser M: personal communication). It is therefore likely that a major proportion of the black-pigmented material is inhaled elemental carbon.
In conclusion, in this cross-sectional study, we found a dose-dependent, inverse association between the carbon content of airway macrophages and $\mathrm{FEV}_{1}, \mathrm{FEF}_{25-75}$, and FVC in healthy children. Since we directly assessed the carbon content of airway macrophages, our data strengthen the evidence for a causal association between the inhalation of carbonaceous particles and impaired lung function in children.

Supported in part by a research agreement (02-1) with the Health Effects Institute.

Prof. Grigg reports being a member of the U.K. Government Expert Panel on Air Quality Standards. Dr. Rushton reports having been a member of the Industrial Injuries Advisory Council of the U.K. Department of Works and Pensions from 1994 to 2004 and being a member of the Committee on Toxicity of Chemicals in Food, Consumer Products, and the Environment of the U.K. Food Standard Agency. No other potential conflict of interest relevant to this article was reported.

We are indebted to Catherine Mallon and Neil Cooper of the Leicester City Council Pollution Control Group for providing the modeled PM data, to Robert Harris of the Institute of Environment and Health for calculating the grid reference points, to Caroline Beardsmore for advice on recruitment, and to the local education authorities, head teachers, and especially the children who participated in this study and their parents.

\section{REFERENCES}

1. Artinano B, Salvador P, Alonso DG Querol X, Alastuey A. Influence of traffic on the PM10 and PM2.5 urban aeroso fractions in Madrid (Spain). Sci Total Environ 2004;334-335:111-23.

2. Air Quality Expert Group. What is causing the health effects of particles? In: Pilling $\mathrm{M}$, ed. Particulate matter in the United Kindom. London: Department for the Environment, Food and Rural Affairs, 2005:29-39. (Also available at http://www. defra.gov.uk/environment/airquality/ aqeg/particulate-matter/index.htm.)

3. Gauderman WJ, Avol E, Gilliland F, et al. The effect of air pollution on lung development from 10 to 18 years of age. N Engl J Med 2004;351:1057-67. [Erratum, N Engl J Med 2005;352:1276.]

4. Finch GL, Hobbs $\mathrm{CH}$, Blair LF, et al. Effects of subchronic inhalation exposure of rats to emissions from a diesel engine burning soybean oil-derived biodiesel fuel Inhal Toxicol 2002;14:1017-48.

5. Strom KA, Garg BD, Johnson JT, D'Arcy JB, Smiler KL. Inhaled particle retention in rats receiving low exposures of diesel exhaust. J Toxicol Environ Health 1990;29:377-98.

6. Brauer M, Avila-Casado C, Fortoul TI Vedal S, Stevens B, Churg A. Air pollution and retained particles in the lung. Environ Health Perspect 2001;109:1039-43.

7. Fireman EM, Lerman Y, Ganor E, et al. Induced sputum assessment in New York City firefighters exposed to World
Trade Center dust. Environ Health Perspect 2004;112:1564-9.

8. Daigle CC, Chalupa DC, Gibb FR, et al. Ultrafine particle deposition in humans during rest and exercise. Inhal Toxico 2003;15:539-52.

9. Bennett WD, Zeman KL. Effect of body size on breathing pattern and fine-particle deposition in children. J Appl Physiol 2004;97:821-6.

10. Bennett WD, Zeman KL, Kim C. Vari ability of fine particle deposition in healthy adults: effect of age and gender. Am J Respir Crit Care Med 1996;153:1641-7.

11. Pierse N, Rushton L, Harris RS, Kuehni CE, Silverman M, Grigg J. Locally generated particulate pollution and respiratory symptoms in young children. Tho$\operatorname{rax} 2006 ; 61: 216-20$

12. Air Quality Expert Group. Introduc tion. In: Pilling M, ed. Particulate matter in the United Kindom. London: Department for the Environment, Food and Rural Af fairs, 2005:6-15. (Also available at http:/ www.defra.gov.uk/environment/airquality/ aqeg/particulate-matter/index.htm.) 13. Lay JC, Bennett WD, Kim CS, Devlin RB Bromberg PA. Retention and intracellula distribution of instilled iron oxide particles in human alveolar macrophages. Am J Respir Cell Mol Biol 1998;18:687-95. 14. Aaron DJ, Kriska AM, Dearwater SR et al. The epidemiology of leisure physical activity in an adolescent population. Med Sci Sports Exerc 1993;25:847-53.
15. Kriska AM, Knowler WC, Laporte RE, et al. Development of questionnaire to examine relationship of physical activity and diabetes in Pima Indians. Diabetes Care 1990;13:401-11.

16. Feyerabend C, Russell MAH. A rapid gas-liquid chromatographic method for the determination of cotinine and nicotine in biological fluids. J Pharm Pharmacol 1990;42:450-2.

17. McNeill AD, Jarvis MJ, West R, Russell MA, Bryant A. Saliva cotinine as an indicator of cigarette smoking in adolescents. Br J Addict 1987;82:1355-60.

18. Jarvis MJ, Strachan DP, Feyerabend C. Determinants of passive smoking in children in Edinburgh, Scotland. Am J Public Health 1992;82:1225-9.

19. American Thoracic Society. Standardization of spirometry, 1994 update. Am J Respir Crit Care Med 1995;152:1107-36.

20. Quanjer PH, Tammeling GJ, Cotes JE, Pedersen OF, Peslin R, Yernault JC. Lung volumes and forced ventilatory flows: Report Working Party Standardization of Lung Function Tests, European Community for Steel and Coal: official statement of the European Respiratory Society. Eur Respir J Suppl 1993;16:5-40.

21. Polgar G, Weng TR. The functional development of the respiratory system from the period of gestation to adulthood. Am Rev Respir Dis 1979;120:625-95.

22. Knudson RJ, Lebowitz MD, Holberg CJ, Burrows B. Changes in the normal max- 
imal expiratory flow-volume curve with growth and aging. Am Rev Respir Dis 1983;127:725-34

23. Rosenthal M, Bain SH, Cramer D, et al. Lung function in white children aged 4 to 19 years. I. Spirometry. Thorax 1993 48:794-802.

24. Cataldo D, Foidart JM, Lau L, Bartsch P, Djukanovic R, Louis R. Induced sputum: comparison between isotonic and hypertonic saline solution inhalation in patients with asthma. Chest 2001;120:1815-21.

25. Brightling CE, Ward R, Woltmann G, et al. Induced sputum inflammatory mediator concentrations in eosinophilic bronchitis and asthma. Am J Respir Crit Care Med 2000;162:878-82.

26. Pavord ID, Pizzichini MM, Pizzichin $\mathrm{E}$, Hargreave FE. The use of induced sputum to investigate airway inflammation. Thorax 1997;52:498-501.

27. Kulkarni NS, Prudon B, Panditi SL, Abebe Y, Grigg J. Carbon loading of alveolar macrophages in adults and children exposed to biomass smoke particles. Sci Total Environ 2005;345:23-30.
28. Leicester City Council Pollution Control Group. Review and assessment of ai quality in Leicester. 2000. (Accessed June 9, 2006, at http://www.leicester.gov. uk/your-council--services/regenerationculture/cl/environmental-health--licensing/ pollution-control/air-quality/review.)

29. Horak F Jr, Studnicka M, Gartner C, et al. Particulate matter and lung function growth in children: a 3-yr follow-up study in Austrian schoolchildren. Eur Respir 2002;19:838-45.

30. He QC, Lioy PJ, Wilson WE, Chapman RS. Effects of air pollution on children's pulmonary function in urban and suburban areas of Wuhan, People's Republic of China. Arch Environ Health 1993;48:382-91.

31. Alexis NE, Soukup J, Nierkens S, Becker S. Association between airway hyperreactivity and bronchial macrophage dysfunction in individuals with mild asthma. Am J Physiol Lung Cell Mol Physio 2001;280:L369-L375.

32. Brainard JS, Jones AP, Bateman IJ, Lovett AA, Fallon PJ. Modelling environmental equity: access to air quality in Bir- mingham, England. Environ Plan A 2002, 34:695-716. (Also available at http://publish. uwo.ca/ jbaxter6/Brainard_et_al_2002_ env_equity.pdf.)

33. Alexis NE, Hu SC, Zeman K, Alter T, Bennett WD. Induced sputum derives from the central airways: confirmation using a radiolabeled aerosol bolus delivery technique. Am J Respir Crit Care Med 2001; 164:1964-70.

34. Fireman E, Greif J, Schwarz Y, et al. Assessment of hazardous dust exposure by BAL and induced sputum. Chest 1999; 115:1720-8. [Erratum, Chest 1999;116: 588.]

35. Gibson PG, Simpson JL, Hankin R, Powell H, Henry RL. Relationship between induced sputum eosinophils and the clinical pattern of childhood asthma. Thorax 2003;58:116-21.

36. Bunn HJ, Dinsdale D, Smith T, Grigg J. Ultrafine particles in alveolar macrophages from normal children. Thorax 2001;56: 932-4.

Copyright (๑) 2006 Massachusetts Medical Society. 